\title{
Tectonic control on the formation of Roskilde Fjord, central Sjælland, Denmark
}

\author{
Stig A. Schack Pedersen and Peter Gravesen
}

Roskilde Fjord is a characteristic N-S-trending geomorphological element in north-east Sjælland (Fig. 1). The eastern coastline of the fjord forms a nearly straight, SSENNW-trending lineament from the town of Roskilde to the coastal areas at Kattegat. Due to the records from wells, it has long been known that a fault zone has to be present along this lineament (Bondesen 1979). The fault is named after the fjord: the Roskilde Fjord Fault (Fig. 2). However, a detailed analysis of the well data in the Roskilde area has shown that a number of minor faults are present, superposed by various landscape elements. These are the inner fjord and valley distributary at Roskilde, the Kornerup $\AA$ valley, the inlet of Lejre Vig and its contributory, and the peninsula of Bognæs (Figs 1, 2).

In this paper we propose a lithostratigraphic division of the Cenozoic deposits and their dynamic development in the Roskilde area. A distribution of the faults with estimated maximum displacements is presented, and their relations to the geomorphological features are outlined. The description is based on several years' studies of the Roskilde Fjord fault complex and presented here due to the recent interest in neotectonics in Denmark and environmental considerations focused on Roskilde Fjord (Gravesen \& Pedersen 2005).

\section{Stratigraphy of the Roskilde area}

The Palaeogene and Quaternary stratigraphy of the area is briefly outlined here based on well data and a few sand and gravel pit outcrops (Gravesen \& Pedersen 2005). The Palaeogene deposits in the area include Danian and Selandian formations (65.5 to 58.7 Ma). The late Danian København Kalk Formation consists of calcisiltitic and calcarenitic yellow-white limestone with some thick chert layers (Thomsen 1995). The overlying, early Selandian deposits were laid down after a period of erosion and often begin with glauconitic conglomerate and greensand of the Lellinge Greensand Formation followed by olive grey glauconitic silty limestone, sand and clay (Clemmensen \& Thomsen 2005). The pre-Quaternary unconformity thus truncates Danian as well as Selandian units.
The oldest Quaternary deposits are probably from the late Saalian (150-130 ka BP). The clayey tills and sand layers are found in deep buried valleys down to $80 \mathrm{~m}$ below the surface. The deposits are known from wells but are difficult to date precisely. Jacobsen (1985) also suggested that Saalian deposits were the oldest Quaternary deposits in the area. From the early Middle Weichselian thin and fragmented sand layers were deposited in rivers and lakes, and the surficial processes possibly initiated the valley formation $c .70-55$ ka BP. A Middle Weichselian ice stream from the east, the 55-50 ka BP Old Baltic Ice Stream, deposited the Ristinge Klint Till Formation, characterised by reddish staining of the clayey and sandy tills (Houmark-Nielsen 2010). The Late Weichselian Himmelev Formation consists of cross-bedded meltwater sand and gravel deposited by braided streams from the north (Jacobsen 1985), indicat-

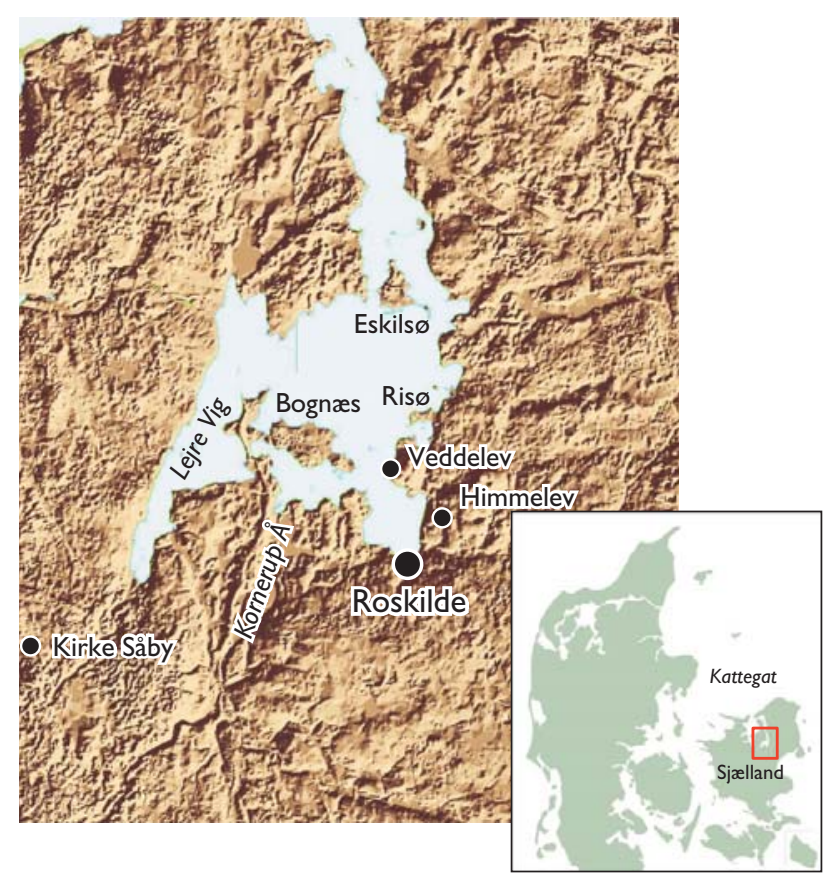

Fig. 1. Terrain model of the Roskilde area and index map of Denmark showing the location of the area in focus. Note the strong S-N-trending lineament including the linear coast lines of Roskilde Fjord. 


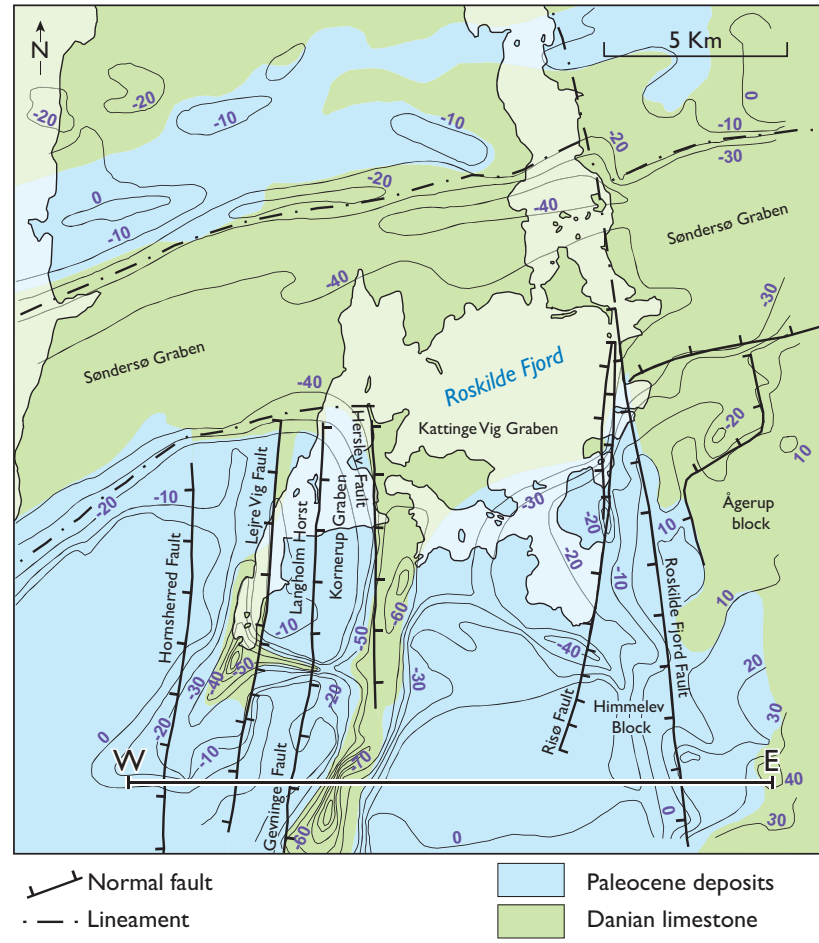

Fig. 2. Geological map of the formations occurring on the pre-Quaternary unconformity surface and location of the cross-section shown in Fig. 4. The contour lines show the depth in metres to the pre-Quaternary unconformity based on well data.

ing deposition at the southern front of the melting Kattegat Ice Stream at $c .26 \mathrm{ka} \mathrm{BP}$. This unit is overlain by the grey to brown, massive Mid Danish Till Formation deposited by the ice stream from north-east during the Last Glacial Maximum (Houmark-Nielsen 1987, 2010). The Mid Danish Till Formation is overlain by the Hedeland Formation, which is a very coarse-grained, cross-bedded sand/gravel formation deposited as a proximal sandur and in meltwater channels (Jacobsen 1985). The last ice advance, the Young Baltic Ice Advance, was separated into two. The first, the East Jylland Advance from the south-east and east deposited the East Jylland Till Formation of grey and brown clayey till at 19-18 ka BP (Houmark-Nielsen 2010). In the following period, which was free of ice cover, glaciolacustrine sediments were deposited. The last advance from the east and south-east deposited the brown, clayey Bælthav Till Formation (18-17 ka BP). During the final melting of the last glaciers the Vindinge Formation consisting of fine-grained sand, silt and clay was deposited in a dead ice landscape. Marine Holocene sand and mud deposits are found along the coast of Roskilde Fjord, while freshwater deposits occur along small streams and in lakes.

\section{Method of cross-section construction}

The analysis of the subsurface geology in the Roskilde Fjord area was carried out by the construction of a large number of mainly E-W-trending cross-sections perpendicular to the interpreted strike of fault features. The cross-sections were constructed in $\operatorname{ArcGIS}^{\odot}$, using well data from the Jupiter database along chosen sections with a bandwidth of $1 \mathrm{~km}$. Maps were constructed from a selection of these wells, providing information on the depth to the pre-Quaternary unconformity and the local lithology at the pre-Quaternary surface (Fig. 2). The pre-Quaternary unconfomity map was produced by an integration over the well data points using ArcGIS ${ }^{\odot}$.

\section{Depth to the pre-Quaternary unconformity}

The map of the depth to the pre-Quaternary unconformity (Fig. 2) shows that the surface forms a high plateau to the east of Roskilde, reaching a level above $30 \mathrm{~m}$ a.s.l. Along the drainage creek to the south-eastern arm of Roskilde Fjord and along the eastern coastline, the structural contours of the surface of the pre-Quaternary unconformity are closely spaced and trend $\mathrm{N}-\mathrm{S}$, indicating an escarpment parallel to the east coast of the Roskilde Fjord. Below the central part of the southern depression of Roskilde Fjord, where the peninsula of Bognæs is located, the depth to the pre-Quaternary unconformity is more than $40 \mathrm{~m}$ b.s.l. Thus, the level change from east to the central part of Roskilde Fjord is almost $80 \mathrm{~m}$.

The south-western corner of the Roskilde Fjord is dominated by two strong lineaments parallel to the geomorphic features Kornerup $\AA$ and Lejre Vig, where two buried val-

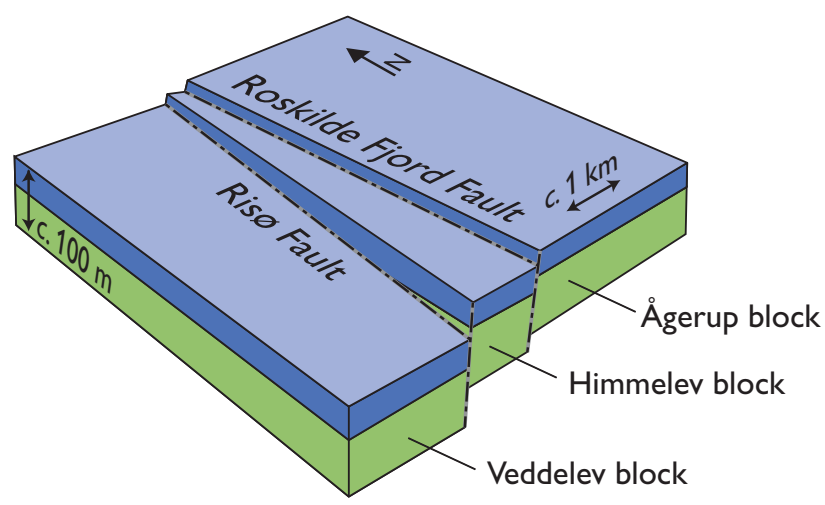

Fig. 3. The block diagram illustrates the relay faults along the east side of Roskilde Fjord. 
leys are eroded to a depth of more than $70 \mathrm{~m}$ b.s.l. (Fig. 1). Between the lineaments the pre-Quaternary unconformity has an elevation of $0-10 \mathrm{~m}$ b.s.l., and farther to the west and south-west at Kirke Såby the surface forms a plateau at about sea level (Fig. 2). To the north the Roskilde Fjord changes from a broad basin to a narrow fjord arm extending northwards. The shift is located to the area around Eskilsø, and the broad basin depression to the south is interpreted as the interference between the Roskild Fjord lineaments and the E-W-trending Søndersø Graben (Fig. 2). This graben system is interpreted as partly tectonically controlled but mainly mirrors a tunnel-valley drainage system to the west related to the Baltic Ice Advance.

\section{Block faulting of Danian limestone and Paleocene limestone and clay}

Only two formations are distinguished at the pre-Quaternary unconformity surface: Danian limestone and Paleocene limestone and clay (Fig. 2). Their distribution follows two rules: Danian limestone either appears where a trench has been carved down to a depth below the base of the Paleocene limestone, greensand and clay, or it appears on elevated plateaux above the Paleocene deposits. The latter is the case east of Roskilde, whereas carved trenches are seen below the Kornerup $\AA$ valley and the Lejre Vig buried valley (Figs 1, 2). The broad, E-W-trending Søndersø Graben belongs in the first group representing a buried valley sandur.

The faults are relay faults (Korstgård 1996). This means that they have a hinge point where the displacement is negligible, and from where the displacement increases along strike (Fig. 3). A culmination of the displacement occurs about $1-4 \mathrm{~km}$ from the hinge point, and then the displacement decreases to another hinge point at the opposite termination of the fault. In the Roskilde fault complex the maximum displacement is calculated to about $60 \mathrm{~m}$, but most faults have displacements only in the range of 10-30 $\mathrm{m}$. The marker horizon used for estimation of the displacement is the boundary between the Danian limestone and the Selandian deposits. This boundary is believed to have been an almost horizontal plane, given that both units are marine successions deposited in the broad shelf environment that dominated the Danish Basin in the Palaeogene.

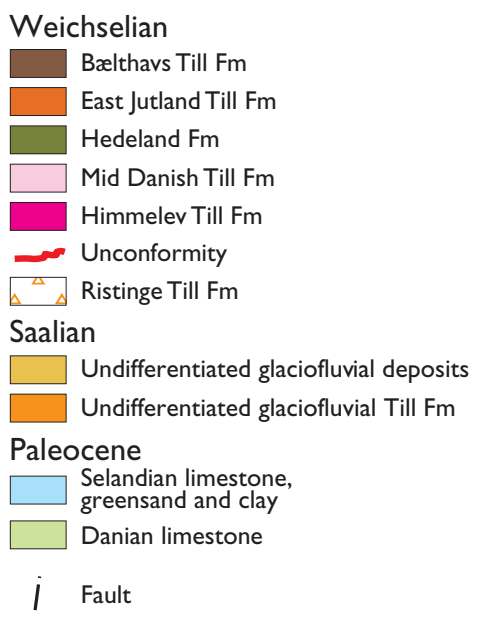

Fig. 4. E-W cross-section of the area south of Roskilde Fjord (location shown in Fig. 2). Below the geological cross-section, two back-stripped cross-sections illustrate the early fault and landscape evolution. Grey vertical lines represent wells.
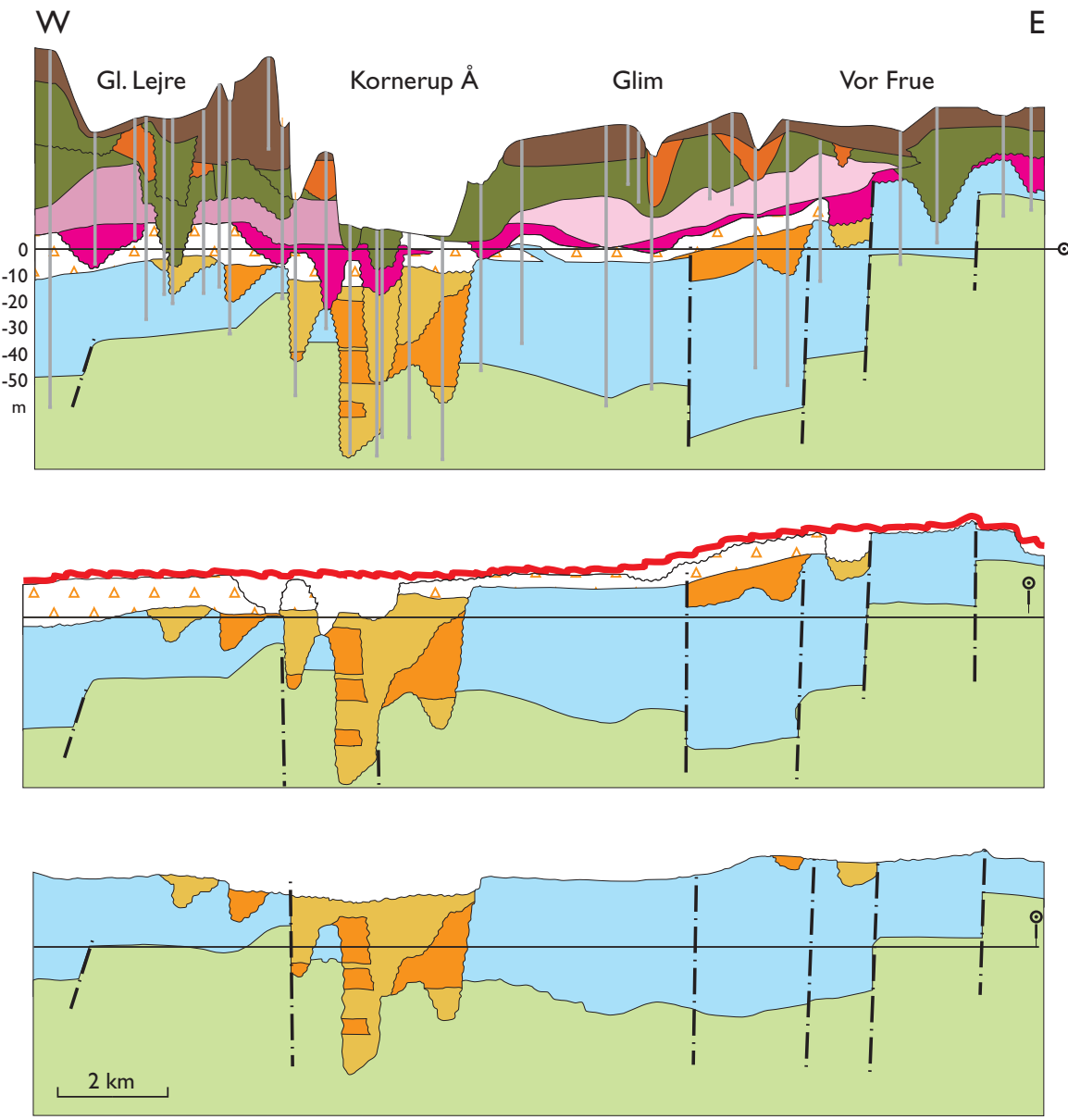


\section{Glaciodynamic development of the Quaternary succession}

The interpretation of the dynamic development includes a palinspastic reconstruction shown in Fig. 4. The interpreted cross-section also illustrates two former structural steps in the development. The first of these goes back to an unconformity that is interpreted as a peneplanation in the main part of the middle-late Weichselian. The second step is a further back-stripping to the supposed Eemian peneplanation after the Saalian glaciation; this scenario illustrates the interpreted faulting of the boundary between the Danian limestone and Selandian unit. Evidently, at this time the Roskilde fault complex had already been active. Furthermore, a deep incised valley along the Kornerup $\AA$ lineament was probably initiated in the Neogene prior to the late Pleistocene. We suggest that deep valley erosion in the Elsterian was succeeded by infill into the valley of meltwater sand and tilly material in the Saalian (Fig. 4). During the Middle Weichselian the Ristinge Advance deposited meltwater sand and the Ristinge Till Formation on a succession that had been faulted. In the beginning of the Late Weichselian, the Last Glacial Maximum initiated the Swedish Ice Advance (Pedersen 2012), which resulted in meltwater streams eroding into the surfaces of downthrown blocks. Renewed erosion and deposition took place in the Kornerup $\AA$ valley, and new valleys were formed in the blocks to the east and to the west along fault lineaments. After the meltwater sand of the Himmelev Formation had filled the valleys to form a relatively even outwash plane surface, the Mid Danish Till Formation covered the area with a more than $10 \mathrm{~m}$ thick clayey basal till.

After the deposition of the Mid Danish Till Formation, a new phase of faulting occurred along the Roskilde Fault. This resulted in a relative uplift of the block to the east and the total vertical displacement by $c .60 \mathrm{~m}$. During the Young Baltic Ice Advance in the Late Weichselian the Mid Danish Till Formation and the underlying Himmelev Formation were eroded away from the elevated area to the east, whereas the sequence was preserved in a down-faulted block to the west. The Young Baltic Ice Advance had oscillating advances and retreats including the East Jutland Ice Advance and the Bælthav Ice Advance (Houmark-Nielsen 2010). At this time the main part of eastern Denmark became covered by a huge outwash plane. At Roskilde this resulted in the deposition of the Hedeland Formation which is the main source for gravel exploitation in the Roskilde area (the previous interpretation of the Hedeland Formation by Jacobsen 1985 is now considered redundant). Thin beds of till are commonly present in this meltwater succession, representing the oscillating ice conditions. Before the final erosion of the valleys and fjord arms the Bælthav Till Formation was deposited shaping the present hummocky moraine plateau landscape.

\section{Conclusions}

The geomorphology of the Roskilde area mirrors a number of tectonic and depositional elements in the subsurface. The fault zones responsible for several terrain lineaments are relay faults that outline an imperfect en échelon pattern. The fault displacements can be calculated from the position of the boundary between the Danian limestone and the Selandian unit. Neotectonic displacement was active shortly after the deposition of the Mid Danish Till Formation. The deepest buried valleys were probably eroded out during the Elsterian glaciation and filled with sand and till during the Saalian glaciation. These valleys were buried during the Weichselian glaciodynamics.

\section{References}

Bondesen, E. 1979: Roskilde, by og landskab - geologi og samfund. In: Birkebæk, F.A. (ed.): 13 bidrag til Roskilde by- og egnshistorie. Roskilde Museums 50 års Jubilæumsskrift, 20-41. Roskilde: Roskilde Museum.

Clemmensen, A. \& Thomsen, E. 2005: Palaeoenvironmental changes across the Danian-Selandian boundary in the North Sea Basin. Palaeogeography, Palaeoclimatology, Palaeoecology 219, 351-394.

Gravesen, P. \& Pedersen, S.A.S. 2005: De geologiske forhold ved Risø. Redegørelse udarbejdet på basis af eksisterende data. Danmarks og Grønlands Geologiske Undersøgelse Rapport 2005/30, 40 pp.

Houmark-Nielsen, M. 1987: Pleistocene stratigraphy and glacial history of the central part of Denmark. Bulletin Geological Society of Denmark, 36, 189 pp.

Houmark-Nielsen, M. 2010: Extent, age and dynamics of Marine Isotope Stage 3 glaciations in the southwestern Baltic Basin. Boreas 39, 343-359.

Jacobsen, E.M. 1985: En råstofgeologisk kortlægning omkring Roskilde. Dansk Geologisk Forening, Årsskrift for 1984, 65-78.

Korstgård, J.A. 1996: Ekstensionsforkastninger. Geologisk Tidsskrift 1, 1-24.

Pedersen, S.A.S. 2012: Glaciodynamic sequence stratigraphy. In: Huuse, M. et al. (eds): Glaciogenic reservoirs and hydrocarbon systems. Geological Society, London, Special Publications 368, 29-51.

Thomsen, E. 1995: Kalk og kridt i den danske undergrund. In: Nielsen, O.B. (ed.): Danmarks geologi fra Kridt til i dag. Aarhus Universitet Geokompendier 1, 32-67.

\footnotetext{
Authors' address

Geological Survey of Denmark and Greenland, Øster Voldgade 10, DK-1350 Copenhagen K, Denmark. E-mail: sasp@geus.dk
} 